Research Article

\title{
Reducing the plight of migrant workers affected by COVID-19
}

\author{
Padma Prasad Khatiwada ${ }^{\text {ab* }}$
}

a. Social Welfare Council (SWC)

b. Padma Kanya Multiple Campus, Tribbuvan University, Kathmandu

Manuscript Received: July 14, 2021

Final Revision: August 31, 2021

Accepted: September 7, 2021

\section{Abstract}

Since the start of the pandemic one and a half years ago, a precarious economic crisis has developed in the country due to the fluctuation in remittance, which had once contributed to nearly one-third of the total GDP. In the initial phase of the pandemic, around 1.5 million migrant workers were expected to return home by losing jobs in major destinations - India, the Middle East and Malaysia - which have over one-fifth of the total migrant workers abroad. On this backdrop, this paper highlights the situation of the Nepali migrant people in the destination during the time of the COVID-19 crisis. The paper utilises existing literature collected through various sources and explores possible areas of intervention. It aims to unpack the impact of the pandemic on migrant workers, remittance flows and the livelihoods of the migrant workers and their family members. The paper concludes that the rate of return may further upsurge depending upon the situation of the spread of the pandemic. The impact of the virus is not limited to a national economy. It is felt by every individual who has lost their jobs, their hopes of getting involved in new jobs and is left unattended by state authorities. Those involved in the informal sectors, particularly the women and those from marginalised communities, are left in a state in which they cannot feed their families and pay their rent due to the effect of lockdowns. To reduce the impact of the pandemic on migrant workers, both the government and non-government development partners must involve in the early recovery work aimed at generating information on the impact of COVID 19 and concentrating on the immediate priorities of those impacted. The priorities should be set based on the current living condition, by utilising best practices available and undertaking measures made up of the capsule of identification, awareness, organisation, putting the victims first and uncompromised monitoring for possible areas of intervention in local communities. These strategies should aim for reintegration by adopting the principle of informed choice of the workers.

Keywords: COVID, workers, jobs, remittance, priority

* Corresponding author; E-mail: padmapd70@gmail.com, CAuthor(s)

Published by Nepal Public Policy Review and peer-review under responsibility of Policy Research Institute Nepal. Licensed under CREATIVE-COMMONS license CC-BY-NC 4.0 


\section{The outset}

The COVID 19 pandemic has virtually affected everyone around the world and Nepal is not an exception. One of the worst-hit communities is that of migrant workers, who are looking after the most possible alternative as an escape from the fear of the pandemic (ILO, 2020a). Upon arrival in their home country from the destination, they are treated negatively and in many places are even restricted to enter their countries. This leaves them vulnerable to statelessness as well.

Worldwide, nearly 4\% of the global population - 281 million - are international migrants (IOM, 2020a). COVID-19 has not only affected those who have been struggling hard in the destination countries but also the aspirants planning for labour migration. According to the Department of Foreign Employment (DoFE), the only authentic body of the government of Nepal, about 115,000 aspirant migrants had to cancel their plans to go abroad due to the lockdown imposed during the first wave of the COVID -19 and the vaccination issue raised by the receiving countries during the second wave. These people had taken labour permits from the government but could not fly out. Similarly, 328,681 aspirant migrants who had taken preapprovals were also stopped during this period (DOFE, 2020; IOM, 2020b). According to the National Human Rights Commission (NHRC), the coronavirus pandemic has affected migrant workers both inside and in the labour receiving countries. Due to the outbreak of COVID-19 in both labour supply and labour receiving countries and the expiry of VISA or the lack of work permits, the migrant workers have had to face serious problems. As the governments of both countries stopped the regular service of visa issuance and work permit renewal, many of the workers have turned undocumented. According to the NHRC (2020), some of the undocumented workers engaged in domestic work are in an exploitative situation.

In view of the far-reaching impact of COVID 19 on the migrant populations all over the world, and especially on the poorest of the poor among the migrants in/from Nepal, it is time to think of interventions to reduce the impact of COVID 19 on migrant workers, manage the free flow of remittance that stands as a lifeline for the economy of Nepal, and protect the lives of the workers on their way home from destination countries. This study aims to identify the overall situation of the Nepali migrant people working abroad during the time of the COVID19 crisis. Based on the review of literature from various sources, the study proposes possible areas of intervention - by both government and non-governmental sectors - to reduce the impact of the pandemic on migrant workers, remittance flow and the livelihoods of the migrant workers and their families.

\section{Migrant workers employment trend in Nepal}

Nepal faces a poverty challenge despite policies and programmes addressing it since long past. Based on the 2017 data, more than 8.1 million Nepali people are facing multi-dimensional poverty (NPC, 2018). This means they lack access to essential services.

Inequality becomes a major cause of growing unemployment in Nepal, a fact empirically proven (OXFAM, 2019). According to the findings of the Nepal Labour Force Survey (NLFS) $2017 / 18$, among the 20.7 million working-age people, approximately 7.1 million were employed while 908 thousand $(11.4 \%$ ) were unemployed in Nepal. Among them, unemployed females were higher $(13.1 \%)$ compared to males. The report further highlights that around 500,000

\section{Page $\mid 180$}


(2.8\%) people enter Nepal's labour market annually (CBS, 2019). The 2011 census on population and housing showed that almost 50 per cent of Nepal's households had a member who was either working overseas or had returned (CBS, 2014). While this labour migration has a significant positive effect on Nepal's economy, it also has a series of socio-economic impacts on the welfare of Nepali nationals abroad. The exploitation of migrant workers is rife. Aspiring labour migrants too often find themselves in a situation of irregular migration or trafficking due to unscrupulous agents/brokers, lack of proper contract letter indicating assigned terms and conditions as well as the duration of work and facilities (IOM, 2019).

The DoFE, under the Ministry of Labour, Employment and Social Security (MoLESS), is a key source of information on labour migration. It issues and records labour permits to migrants wishing to emigrate for employment. This data has significant limitations. Firstly, it comprises only the number of labour permits issued by the government; importantly, therefore, the large number of Nepalis who go to India are not recorded. The terms of the 1950 Friendship Treaty do not require labour permits for Nepalis wishing to migrate to India for employment. Secondly, by only indicating the number of permits issued, the figures do not explain whether one individual has received multiple permits or whether the permits issued have been used.

Historically, Nepali migrant workers have searched for wage-earning jobs mainly in India. From the mid-1980s, however, Nepalis also started to migrate to the Gulf States and Malaysia for work which resulted in an increase in migrant workers as well as in a proliferation of labour recruitment agencies and brokers. As a result of this, migrant workers suffered a lot due to the lack of awareness, exorbitant fees from brokers and poor monitoring from the concerned institutions. One of the studies conducted by the Nepal Institute of Development Studies (NIDS) showed an instance of debt-bondage, in which youths were both enticed and forced by brokers to go to the third countries, mainly to the Gulf countries, to earn the money needed to pay the debts their forefathers were said to borrow (NIDS, 2010).

The decentralization of passport issuance in Nepal also facilitated the migration of many unskilled and semi-skilled Nepalis. During the past two decades, Nepal has also witnessed an increase in the number of Nepali women seeking work abroad and being gradually recognized as important economic actors. Out of the 72081 new entries of pre-approval for foreign labour, $7178(9.96 \%)$ were females (DoFE, 2021). The risk of exploitation and abuse of women migrant workers is high, particularly in the largely unregulated sectors such as domestic work.

Before 2010, female migration to the Gulf for low skilled work was restricted. A new restriction was put in place in 2012 preventing women under the age of 30 from migrating to the Arab States for domestic work. In 2014, this restriction was expanded to women of all ages. In 2015, a directive reopening migration for female domestic workers aged 24 years and above was issued (DoFE, 2015; ILO, 2015). These measures have met with limited success. There is evidence of women migrants being in situations of risk. The process for Nepalis to migrate for employment is complex and time-consuming, which has spurred the increase of recruitment agencies. It also means that many migrant workers use irregular channels to access foreign employment, instead of following the normal process of obtaining a labour permit (IOM, 2019). 
Some institutions in Nepal - such as CBS, DoFE, Ministry of Health and Population (MoHP), IOM, ILO, universities and research institutes - have initiated and raised the issues of the record-keeping system. However, they lack coordination and integration of data and the system at large is not so effective. Similarly, the Vital Registration Department of the Ministry of General Administration and Federal Affairs has been making effort for regulating migration data. These efforts have not been at the level of use at present. The number of returnee migrant workers due to the COVID-19 pandemic is difficult to figure out in Nepal. Tribhuvan International Airport and the Immigration Office are trying to figure out these data, but have not been able to share the data yet. Nevertheless, some bases can be established to figure out. An estimate made at the end of November 2019 shows that around 500,000 Nepali migrants are in Malaysia, the most popular labour destination for Nepali workers, followed by Qatar (with over 400,000), Saudi Arabia (334,451), the United Arab of Emirates (224,905) and Kuwait (70,000) (DoFE, 2019; IOM, 2019). These five countries alone accommodate over 1.5 million Nepalis.

Due to the fear of COVID-19, more than 700,000 workers have returned from India so far as reported by various media in Nepal and an almost equal number are estimated to return within six months (Kathmandu Post, 2020). Another study by the General Federation of Nepalese Trade Unions (GEFONT) showed that $2.46 \%$ of Nepali workers are completely jobless in Malaysia and Gulf countries. They include the workers with the visa expired, those lacking compliance documents and finally those who have received amnesty. A few of them were also employed or those placed in quarantine as a result of corona infection. Among those with a valid employment contract, around $3 \%$ had not received their wages and nearly $11 \%$ had received only partial wages. GEFONT research further concludes that no provision of overtime - nor other conditions - exists in the contract to explain why the income of the workers decreased (GEFONT, 2020). Another study by ILO also indicated the poor quality of quarantine and suggested the Malaysian government to enable migrant workers to access quarantine facilities that permit social distancing, where available, and ensure safe spaces for women migrant workers and privacy, hygiene and sanitation facilities (ILO, 2020b).

\section{Migrant workers issues in relation to COVID-19 in Nepal}

Workers are equally fearful of the prospect of job loss in the informal sector. If it happens, they cannot feed their families, pay their rent or survive in the city due to the lockdown affecting jobs in construction, manufacturing, restaurants, travel, tourism, and domestic work. When the first phase of the lockdown began on 26 March 2020, people had some money, some food and other items on which to survive. This was also applicable to workers. But now, after more than two months of the complete lockdown during the second wave of the COVID 19 pandemic, they are in a situation in which both the stored food grains and money have been exhausted. This pathetic situation is further precarious for the workers involved in the informal sector who had to remain almost unemployed during the first wave of the pandemic. In many places, having had no savings whatsoever, the economic effects of the crisis were felt immediately by the workers. In Nepal, although the government offered some relief packages during the first wave of the pandemic, they were all in-kind and thus could not meet the necessities felt by the workers. During the second wave of the pandemic, the distribution of the relief package to this sector is said to be less effective. The number of the distributors involved - government and non-government agencies - and the coverage of the supplies did not match the need.

\section{Page| 182}


South Asia, particularly India, where millions of Nepalis are residing as workers, is the land movement of migrant labourers who crossed state borders to reach their villages from the initial time of the lockdown. There interstate transit bus terminals (ISBT) across the country remained crumbled as the migrant workers wanted to go home. This created a precarious situation and added to the fear of the spread of the pandemic. People gathered at one place as a huge crowd and created new hotspots for the virus. During the second wave, the spread of the pandemic towards the places of origin of these returnees, especially in Karnali and sudur paschim (far west) hills, was observed to a greater extent causing deaths of hundreds of people and thousands being infected. According to The Economic Times, an online portal published from India, hundreds of migrant labourers gathered near Bandra Station, Mumbai on 13 April 2020 while trying to go back home. The crowd gathered for more than an hour added to the fear of the spread of the coronavirus and was finally dispersed by the police (The Economic Times, 2020).

The loss of employment abroad will be a huge impact on the families and economies that were dependent on remittances (Informal, 2020). As the Secretary-General of the United Nations said, on 19 March 2020, the COVID pandemic would impact differently on women, who normally bear the additional burden of unpaid care work, loss of paid work (since they are usually and mostly in the informal sector). Further, lacking awareness of and focus on gender concerns, women are most likely to be bypassed by state-provided support if any at all (News 18.com, 2020).

\section{The Policy Setup and response milieu}

The Constitution of Nepal outlines some policy areas regarding migration such as utilizing the skill of migrant workers in national development. The Constitution aims to promote agricultural land in order to address the crisis of food and food insecurity. The Constitution focuses on labour with due respect and dignity and seeks to enhance employment within Nepal. The Constitution aims to make foreign employment free from any type of exploitation by guarantying the rights of the migrant workers and members of their families. It also aims to mobilize the capital and skills of returning migrant workers (IOM, 2019).

The National Planning Commission is the authority for overall coordination among line agencies and the preparation of periodic plans for Nepal's development. For a long period of the periodic plan of Nepal, the migration policy was confined to regulatory functions. The Fifteenth Plan, being implemented at present, has for the first time developed a comprehensive policy on migration. The plan seeks to "accelerate economic growth and emphasizes the importance of migration management." The policy ensures that "... Nepalis have the opportunity to benefit from economic opportunities without needing to migrate, as well as to ensure that immigration is well regulated." The plan has set a strategy to establish a database on migration, which will contain overall demographic information, by applying advanced technology (NPC, 2018; IOM, 2019). The database is expected to be useful to both researchers and policymakers.

The Fifteenth Plan plan has further aimed to make foreign employment safe, secure, respectable and free from exploitation in every stage of migration (IOM, 2020b). In order to make the migration process safe and secure, the government of Nepal has also given priority to bilateral agreements with labour receiving countries. So far the government has been able to conduct 
such agreements with nine countries (Table 1).

Table 1: List of agreements signed between the government of Nepal and destination countries

\begin{tabular}{lll}
\hline Destination Country & Year of agreement & Designation of agreement \\
\hline Qatar & 2005 & General Agreement \\
UAE & 2007,2019 & Memorandum of Understanding \\
Republic of Korea & 2007 & Memorandum of Understanding \\
Bahrain & 2008 & Memorandum of Understanding \\
Japan & 2009 & Directive \\
& 2019 & Memorandum of Cooperation \\
Israel & 2015 & Joint Pilot Program \\
Jordan & 2017 & General Agreement \\
Malaysia & 2018 & Memorandum of Understanding \\
Mauritius & 2019 & Memorandum of Understanding \\
\hline
\end{tabular}

Source: MoLESS, 2020; IOM, 2019.

These agreements give priority to establishing well-coordinated labour diplomacy by harnessing coordination among all stakeholders, including non-resident Nepali associations. Aware of the impact of an open border with India, the government has given priority to the protection of the migrant workers going to India. By policy, the local governments are mandated to register them for the facilities of insurance and welfare funds (NPC, 2019).

Nepal has two main policies to deal with migrant workers: the National Labour Policy, 2014 and the Foreign Employment Policy, 2012. Both policies aim at the promotion of employment opportunities inside the country to end the compulsion to migrate abroad in search of work. The policies further aim to protect migrant workers in countries of destination, particularly those experiencing risks and vulnerabilities.

The Constitution has paved the way for enacting acts, regulations and necessary laws for the smooth operation of development activities to realise Nepali citizens' aspirations and expectations of the Federal Democratic Republic of Nepal. All three levels of government are governed by their own acts and laws. In this context, the Local Government Operation Act 2017 was enacted to facilitate the development activities of local governments. Regarding migration, this act has created avenues for local governments to collect and manage, among many others, migration data, statistics and records which are available locally. The Act has mandated the maintenance of a civil registry and vital statistics known as births, deaths, marriages, divorces and migration. The Act also mandates the record-keeping of both the domestic and foreign labour force (Nepal Law Commission, 2015). The local governments are "equally responsible for the management and operation of employment information centres which can provide financial literacy and skill training for the labour force going abroad (IOM, 2019).

The sectoral policies like the National Population Policy, 2014 aim to manage internal and

\section{Page| 184}


external migration by maximising the engagement of human resources in the productive sector inside the country, by establishing at least one industrial area in every constituency, municipality or district headquarter, by safeguarding Nepalese migrant workers through diplomacy with major countries of destination and by developing sets of information on destination countries' context, language, culture and law (MOPE, 2014).

Targeting the COVID-19 pandemic, the government has thus far conducted some crucial tasks concerning the migrant workers abroad. The government stopped the issuance of labour permits for those seeking to go for foreign employment from 23 February 2020. During the first wave of COVID -19, the government developed various guidelines for the reparation of migrant workers. The guidelines gave priority to the repatriation of migrant workers in vulnerable conditions, including women in special need (IOM, 2020b). Priority was also given to childbearing mothers, people who had lost jobs, sick people, those who had lost family members and the overstayed ones. Among others, they were provided with repatriation assistance (ILO, 2020b).

The repatriation guidelines also have provisions for allocating financial support to the Nepali workers stranded abroad. Such support includes air tickets to return home and other expenses needed to reach home from the Tribhuvan International Airport. The government has also indicated its policy to pay air tickets of the workers willing to return to the companies (in the destination) that laid them off (IOM, 2020b)

Stopping migrant workers from going abroad for work is not a solution. Neither is it in conformity to a human rights perspective. And thus, the government started lifting the ban after witnessing the decline of the first wave of COVID-19. During the initial four months of the first phase of the lockdown - April-July 2020 - none of the migrant workers was found to get permission to go abroad. From the first week of August 2020, the lockdown was gradually lifted, and thus the number of workers going abroad began to increase. Afterwards, the highest flow was witnessed during March/April 2021, when 32,142 Nepali youths went to different labour receiving countries. The female migrant workers were around $7 \%$ of them.

Table 2: Outbound labour migrants update, Nepal, July/August 2020 - May/June 2021

\section{Date}

\section{Migrant Composition}

Male Percent Female Percent

\begin{tabular}{lrrrrrr}
\hline May/June 21 & 3,868 & 94.7 & 218 & 5.3 & 4,086 & 3.0 \\
April/May 21 & 22,609 & 92.8 & 1,754 & 7.2 & 24,363 & 17.8 \\
March/April 21 & 30,035 & 93.4 & 2,107 & 6.6 & 32,142 & 23.4 \\
Feb/March 21 & 18,436 & 93.1 & 1,372 & 6.9 & 19,808 & 14.5 \\
Jan/Feb 21 & 8,542 & 95.8 & 379 & 4.2 & 8,921 & 6.5 \\
Dec 20/Jan 21 & 13,397 & 90.8 & 1,356 & 9.2 & 14,753 & 10.8 \\
Nov/Dec 20 & 11,321 & 91.1 & 1,110 & 8.9 & 12,431 & 9.1 \\
Oct/Nov 20 & 7,486 & 96.0 & 311 & 4.0 & 7,797 & 5.7
\end{tabular}




\begin{tabular}{lrrrrrr} 
Sep/Oct 20 & 7,676 & 94.8 & 421 & 5.2 & 8,097 & 5.9 \\
Aug/Sep 20 & 1,418 & 93.0 & 107 & 7.0 & 1,525 & 1.1 \\
July/Aug 20 & 2,974 & 94.4 & 178 & 5.6 & 3,152 & 2.3 \\
Total & 127,762 & 93.2 & 9,313 & 6.8 & 137,075 & 100.0 \\
\hline
\end{tabular}

Source: DoFE (2021).

During the past 11 months, a total of 137,075 migrant workers got approval from the receiving countries. Out of them, nearly 7\% were females and $93 \%$ were males. Since mid-April 2021, the second wave of COVID-19 began to spread rapidly in Nepal. As a result, the number of workers going abroad decreased sharply to, for example, 4086 during May/June 2021 (Table 2).

During the crisis, the government has the main responsibility to accommodate both the returnees and aspirant migrant workers through policies and programmes. The first and foremost option is the promotion and expansion of agriculture targeting the returnee migrant workers. This also requires giving due attention to the voice and the psychology of the youths planning for foreign migration. An option for them is to support them to start the entrepreneurship of their choice. The government during the 2019/20 budget speech announced that " $\ldots$ youths returning from foreign employment with skills in agriculture will be encouraged to undertake organic farming as a business" (MoF, 2020). How the implementation of this policy went was not reviewed by this fiscal year's budget speech, neither by any other bureaucratic institutions from the local to the central level. As such, there is no knowledge or feedback in terms of the effectiveness of the policy. This year's budget too has announced that youths, women and returned persons from foreign employment will have the opportunity to involve in small and medium enterprises and commercial agriculture $\mathrm{MoF}$, 2021).

The interested returnee migrant workers need to be encouraged for subsistence agriculture without destroying the principle of 'subsistence.' It should aim to transform 'household subsistence' to 'national subsistence. Equally important is to make agriculture work prestigious by diversifying agriculture into food grains, vegetables, medicinal plants, animals and meats, forest products, etc.

\section{Conclusion}

Given the far-reaching impact of COVID 19 on migrant populations all over the world and especially on the poorest of the poor among the migrants in/from Nepal, we need to think of interventions to reduce the impact of the pandemic on workers, remittances and their livelihoods. The Ministry of Labour Employment and Social Security must be involved in the early recovery work by generating information on the impact of COVID -19 on foreign migrant workers. Information can be generated from the review of media clips, news broadcasts and online portals based on a brief questionnaire or checklist. The information should provide situational updates and analyses of the difficulties encountered by workers so that it becomes clear early on what immediate, medium-term and long-term interventions should be made to support and protect the workers.

\section{Page| 186}


Since this pandemic is striking every single citizen challenging the existing disaster management framework (News 18.com, 2020), there is an urgent need to develop a system to understand and foresee the overall effects and impacts of the pandemic, which are not clear yet. Every disaster has its own features and devastating potential, both immediate and long-term. A framework that has been useful to deal with one disaster, such as the 2015 earthquake in Nepal, may not work for the other. As of now, no one knows the scale and real intensity of the effect of the pandemic. What we are talking about are only the early signs.

Every one of the returning migrant workers is the potential carrier of the virus to their places of origin (Firstpost, 2020). As they return to remote areas that severely lack tracing, testing and hospital facilities, the migrants risk being the cause to worsen the entire COVID-19 scenario in the country (News18.com, 2020). The disaster has already crossed all inter-state/province borders and spread into every nook and corner of the country. Coordination among all institutions at national, subnational and local levels is essential to mitigate the impact of the pandemic and halt it. No one actor or institution - whatever well off or resourceful - can solve the problem alone.

\section{Recommendations}

The government of Nepal should create an enabling environment to undertake the following capsule of activities in an integrated manner.

1. Identify the migrant workers: State authorities, particularly, the MOLESS should concentrate on Immediate priorities of returned workers. The priorities should focus on personal and demographic identification of the workers and their current living condition (mixed up with family or self-isolated, quarantined or in other special conditions).

2. Make migrant workers aware and sensitised: Keep workers sensitised and aware of services and facilities available to them through focused publicity and awareness campaigns and by using public communication systems and services of volunteers and non-government organisations (Informal, 2020). The information of services and other measures taken by the government should reach down to ward levels and communities.

3. Organise quality transit and medical facilities: Quarantine or self-isolation shelters should be organised keeping in view of precautions that should be taken, such as physical or social distancing, case tracing and check-up facilities, quarantine or hospitalisation. This is possible only by implementing related directives issued by the government, such as the quarantine guidelines, and ensuring coordination and cooperation among line government agencies, development partners, local non-governmental organisations as well as the private sector.

4. Put the migrant workers and their issues first: In the profit-oriented mode of production, the value of work is generally ignored during the crisis, such as the one posed by COVID-19. Such crises are instead seen as an opportunity to earn extra benefits by laying off employees, reducing payment or forcing the employees to stay on unpaid leaves. Several immigrant labours faced such troubles during the pandemic. To address them requires a specific policy providing for the care and support to those at risk and uncertainty of work. It's good that the government has initiated the repatriation of the migrants from Gulf countries and Malaysia. The budget speech for the fiscal year 
2020/21 has the plan to create at least 700,000 employment opportunities many of which are aimed at the returned migrant workers. However, the modality of the employment and the sectors of mobilisation have not been developed. The government should, without delay, identify the sectors that match the needs and skills of migrant workers and develop the modality of employing them

5. Put in place a monitoring system: In order to reduce the risk of exploitation and abuse of migrant workers in general and women migrant workers in particular, a strict mechanism should be in place to regularly monitor the situation of the workers, particularly of those in the unregulated sectors such as domestic work, in the Gulf countries in particular. The outcomes of monitoring should be regularly reviewed and responded to.

Nepal does not have reliable data on workers affected by COVID-19. The main priority should, thus, be on collecting data of COVID-19-affected workers using references from international experiences and emerging trends and experiences in the context of returnee migrants' reintegration and rehabilitation.

\section{References}

CBS (2014).Population Monograph of Nepal Vol. I. https:/ /cbs.gov.np/wpcontent/upLoads/2018/ 12/Population-Monograph-of-Nepal-2014-Volume-I-FinalPrintReady1.pdf. (Accessed: 30 August 2021).

CBS (2019). Nepal labour force survey report 2017/18. http://wwwhttps:/ / nepalindata.com/ media/resources/items/20/bNLFS-III_Final-Report.pdf.dofe.gov.np/ yearly. aspx (Accessed: 26th May 2020).

DoFE (2015). Baideshike Rojgarma Gharelu Kamdarlai Byabasthit Garne Sambandhi (Tesro Sansodhan) Nirdeshika 2073 (in Nepali). https:/ / dofe.gov.np/Directoriate.aspx (Accessed: $30^{\text {th }}$ August 2021).

DoFE (2019). Yearly progress on approval. http://www.dofe.gov.np/yearly.aspx (Accessed: 25th May 2021).

DoFE (2020). Yearly progress on approval. http://www.dofe.gov.np/yearly.aspx (Accessed: 25th May 2021).

DoFE (2021). Countrywise Labour Approval for FY 2077/ 78 (2020-07-16 to 2021-07-15), https://dofe.gov.np/monthly.aspx. (Accessed: 30 August 2021)

GEFONT (2020). Rapid Assessment on the problems faced by the workers due to COVID-19. https://www.gefont.org/VH156011 (Accessed: 25 August 2021).

Kathmandu Post (2020). With hundreds of thousands of migrants predicted to return home, Nepal needs to brace for a crisis. https://kathmandupost.com/national/2020/04/22/withhundreds-of-thousands-of-migrants-predicted-to-return-home-nepal-needs-tobrace-for-a-crisis (Accessed: 30 August 2021).

ILO (2015). No easy exit - Migration bans affecting women from Nepal. Fundamental Principles and Rights at Work. Labour Migration Branch, ILO Geneva. https:/ /www. ilo.org/wcmsp5/groups/public/---ed_norm/---declaration/documents/ publication/wcms_428686.pdf.

\section{Page $\mid 188$}


ILO (2020a). Impact of COV ID-19 on Nepali migrant workers: protecting Nepali migrant workers during the health and economic. ILO Country Office Nepal, International Labour Organization

Crisis. https:/ / www.ilo.org/wcmsp5/groups/public/---asia/---ro-bangkok/---ilokathmandu/documents/briefingnote/wcms_748917.pdf.

ILO (2020b). COVID-19: Impact on migrant workers and country response in Malaysia. Regional Office for Asia and the Pacific, International Labour Organization. https://www.ilo.org/wcmsp5/groups/public/---asia/---ro-bangkok/documents/briefingnote/wcms_741512.pdf.

IOM (2019). Migration in Nepal: A country profile 2019. International Organization for Migration, Kathmandu. https://publications.iom.int/books/migration-nepal-country-profile-2019. (Accessed: 1 September 2021).

IOM (2020a). World migration report 2020. International Organization for

Migration. https://publications.iom.int/system/files/pdf/wmr_2020.pdf. (Accessed: 1 September 2021).

IOM (2020b). Status of Nepali migrant workers in relation to COV ID-19. International Organization for Migration. https://publications.iom.int/books/status-nepali-migrant-workers-relation-covid-19. (Accessed: 1 September 2021).

MoF (2020). Budget speech of government of Nepal 2020/21. Ministry of Finance. https://www.mof.gov.np/uploads/document/file/बजेट_वक्तव्य_२०७७_website_20201118075339.pdf (Accessed: 1 September 2021)

MoF (2021). Budget speech of government of Nepal 2021/22 Budget Speech (Final). Ministry of Finance https://www.mof.gov.np/uploads/document/file/Budget $\% 20$ Speech\%20(Final)\%20Full_20210530100738.pdf. (Accessed: 30th July 2021)

MOLESS (2020). Nepal labour migration report 2020. Ministry of Labour, Employment and Social Security, Singhadarbar, Kathmandu. https:/ / moless.gou.np/ wp-content/ uploads/2020/03/Migration-Report-2020-English.pdf. (Accessed: 29th July 2021).

MoPE (2014). Population policy of Nepal 2014. https:/ / nepalindata.com/ resource/ national-population--policy--2071-/. (Accessed: 28th July 2020).

NHRC (2020). COV ID-19 Mahamariko Chapetama Nepali Aapravasi Sramikharuko Adhikar Adbyayan Pratibedan, 2077. National Human Rights Commission, Kathmandu.

News 18.com (2020) Pandemic, Infodemic' and 'Ecodemic': The Covid-19 Trilemma. bttps:/ / www.news18.com/news/opinion/pandemic-infodemic-and-ecodemic-the-covid-19-trilemma-2573785.html (Accessed: 1 September 2021).

NIDS (2010). Migration for foreign employment: an unpublished survey report conducted in three districts of Nepal (Khotang, Okhaldhunga and Ramechhap) submitted to Swiss Agency for Development and Cooperation (SDC) Nepal Office. https:/ / www.researchgate. net/publication/280495829_Migration_for_Foreign_Employment (Accessed: 1 September 2021)

Nepal Law Commission (2017). Sthaniya Sarkar Sanchalan Ain 2074 [Local Government Operation Act 2017). www.lawcommission.gov.np/np/wp-content/up- 


$$
\text { loads } / 2020 / 12 / \text { स्थानीय-सरकार-सज्चालन-ऐन-२०७४.pdf }
$$

NPC (2018). Nepal multi-dimensional poverty index: analysis towards action. https:/ /www. npc.gov.np/images/category/Nepal_MPI.pdf. (Accessed: 1 September 2021). (Accessed: 1 September 2021)

NPC (2019). Fifteenth periodic plan (2019/20-2023/24), National Planning Commission, GoN (page 331-332). https://npc.gov.np/images/category/15th_plan_English_Version.pdf. (Accessed: 1 September 2021).

OXFAM (2019) Fighting inequality in Nepal: The road to prosperity. https:/ / oxfamilibrary. openrepository.com / bitstream/ handle/10546/620607/bp-fighting-inequality-nepal-110119-en.pdf(Accessed: 1 September 2021).

The Economic Times (2020). Migrant workers come out on road; say want to travel back home. https:/ / economictimes.indiatimes.com/news/politics-and-nation/ migrant-workers-come-out-on-road-say-want-to-travel-back-home/articleshow/75143667.cms. (Accessed: 1 September 2021).

\begin{abstract}
About Authors
Dr. Padma Prasad Khatiwada, is a Faculty/Instructor for PhD with Coursework, MPhil and MA, in Tribhuvan University. Recently appointed by the Government of Nepal as a Vice Chairperson of Social Welfare Council, Dr. Khatiwada has contributed as Team Leader over 100 research studies on social sciences, presented papers in more than 100 venues (Nepal, 61 districts and over 20 different countries) and supervised PhD, MPhil and MA theses in the University. Well renowned as a human rights activist in social sector and policy contributor for TU, National Planning Commission, Ministry of Health and Population, Ministry of Women, Children and Senior Citizen, Dr. Khatiwada also serves as a Core Committee Member of South Asia Alliance for Poverty Eradication, General Secretary of Human Rights Alliance and dozen other similar social and professional organisations.
\end{abstract}

